\title{
Environmental Impact Assessment for an Absorption Heat Transformer
}

\author{
Jorge Avelino Domínguez Patiño, Antonio Rodríguez Martínez², \\ Rosenberg Javier Romero², Jonathan Ibarra-Bahena' ${ }^{2}$, Martha Lilia Domínguez Patiño1 \\ ${ }^{1}$ FCQel (Facultad de Ciencias Químicas e Ingeniería), Universidad Autónoma del Estado de Morelos, \\ Cuernavaca, México \\ ${ }^{2}$ CIICAp (Centro de Investigación en Ingeniería y Ciencias Aplicadas), Universidad Autónoma del Estado de \\ Morelos, Cuernavaca, México \\ Email: jorge.dominguez@uaem.mx
}

Received 9 June 2016; accepted 19 July 2016; published 22 July 2016

Copyright (C) 2016 by authors and Scientific Research Publishing Inc.

This work is licensed under the Creative Commons Attribution International License (CC BY).

http://creativecommons.org/licenses/by/4.0/

cC) (i) Open Access

\section{Abstract}

This study presents the environmental impact assessment of an absorption heat transformer designed to recover $1 \mathrm{~kW}$ of thermal energy from each $2 \mathrm{~kW}$ of waste heat supplies. The net contribution of the heat transformer is a load avoided of $0.665 \mathrm{~kg} \mathrm{CO}_{2}$ equivalents; the recovery process avoids $0.729 \mathrm{~kg} \mathrm{CO}_{2}$ equivalents and the major contribution to the environment impacts is the pumping process with $0.0437 \mathrm{~kg} \mathrm{CO}_{2}$ equivalents for each $1 \mathrm{kWh}$ recovered. The study results show that absorption heat transformer is a good environmental option because it produces useful energy from waste heat and the final result is an environmental impact diminution.

\section{Keywords}

Environmental Impact, Life Cycle Assessment, LCA, Absorption Heat Transformer, Waste Heat Recovery

\section{Introduction}

The electricity consumption by the industry is $42.3 \%$ which is equivalent to 709 Mtoe (million tonnes of oil equivalent) [1]. The industrial sector requires energy for pumping systems, cooling and heating systems and illumination systems.

A heat transformer is a device which can deliver heat a higher temperature than the temperature of the fluid which is fed, normally waste heat energy from industrial processes or renewable energy such as solar or geothermal energy [2]. 
Energy recovery is an important topic in industries where high amounts of heat are wasted. Many industrial processes require large amounts of steam or hot water to heat the process streams.

Absorption heat transformers (AHTs) are thermo-mechanical devices in which the main feature is the recovery of waste heat. AHTs are capable of recovering a large amount of energy and increase its temperature, using part of the same energy as power in a thermodynamic cycle. The increased temperature inside any closed thermodynamic system is a consequence of the increment of pressure. The difference of pressure in an AHT is obtained by means of a relatively small amount of mechanical energy supplied by a mechanical pump to move a fluid [3].

Large quantities of heat from industries have been rejected to the atmosphere, which not only wastes energy but also pollutes the environment [4].

As a very effective device, the AHT can be applied to improve low-grade waste heat with temperatures ranging from $60^{\circ} \mathrm{C}$ to $100^{\circ} \mathrm{C}$. The AHT system can effectively recover about $50 \%$ of this waste heat and give an opportunity to reuse it in industrial processes [5]

The European Commission presented the Life Cycle Assessment (LCA) as an important framework for evaluating the environmental impact of products, processes or systems [6].

LCA quantifies energy, materials and wastes released to the environment and performs the impact assessment of those inputs and outputs. The application of LCA follows a standardized procedure described in ISO 14040: 2006 [7] and ISO 14044:2006 [8].

LCA studies help to avoid resolving one environmental problem while creating others: this unwanted "shifting of burdens" is where you reduce the environmental impact at one point in the life cycle, only to increase it at another point. Therefore, LCA helps to avoid, for example, causing waste-related issues while improving production technologies, increasing land use or acid rain while reducing greenhouse gases, or increasing emissions in one country while reducing them in another. Life Cycle Assessment is therefore a vital and powerful decision support tool, complementing other methods, which are equally necessary to help effectively and efficiently make consumption and production more sustainable [9].

Many theoretical and experimental studies of AHT have been carried out [10] [11], and in those completed reviews there is not any LCA for AHT to show the $\mathrm{CO}_{2}$ equivalent for each recovered energy unit.

\section{AHT System Description}

The AHT system consists basically of five plate heat exchangers (generator, condenser, evaporator, recovery and absorber), piping and accessories, two pumps and Lithium Bromide ( $\mathrm{LiBr}$ ) solution as a working fluid.

A constant heat waste is supply to the generator in order to vaporize a part of the working fluid (water) to the aqueous $\mathrm{LiBr}$ solution at low pressure. The vaporized working fluid flows to the condenser, delivering an amount of heat at close ambient temperature. The liquid leaving the condenser is pumped, to the evaporator at a higher-pressure zone. The working fluid is then evaporated at high pressure into the evaporator using a second quantity of heat waste at an intermediate temperature. At same time, the vaporized working fluid goes to the absorber, inside of which, it is absorbed by the concentrated in absorbent solution; this stream comes from the generator. The absorption process delivers useful heat at higher temperature. Figure 1 shows a schematic block diagram of the AHT function system.

\section{Methodology}

The increased awareness of the importance of environmental protection, and the possible impacts associated with products (including services), both manufactured and consumed, has increased interest in the development of methods to better understand and address these impacts. One of the techniques used for this purpose is LCA [7] [8]. There are four phases in an LCA study:

1) the goal and scope definition phase.

2) the Life Cycle Inventory analysis phase (LCI phase), it is an inventory of input/output data with regard to the system being studied. It involves collection of the data necessary to meet the goals of the defined study.

3) The Life Cycle Impact Assessment phase (LCIA) is the third phase of the LCA. The purpose of LCIA is to provide additional information to help assess a product system's LCI results so as to better understand their environmental significance. LCIA phase aimed at understanding and evaluating the magnitude and significance of the potential environmental impacts for a product system throughout the life cycle of the product. The method 
use for this study is IPCC 2007 which is a method developed by the International Panel on Climate Change. This method lists the climate change factors of IPCC with a timeframe of 20, 100 and 500 years [12], the timeframe chosen was 100 years.

4) Life cycle interpretation is the final phase of the LCA procedure, in which the results of an LCI or an LCIA, or both, are summarized and discussed as a basis for conclusions, recommendations and decision-making in accordance with the goal and scope definition.

Figure 2 shows a schematic diagram of the LCA of an AHT.

\section{Life Cycle Assessment of AHT}

\subsection{The Goal and Scope Definition Phase}

The Goal: The purpose of this study is assessment the environmental load of an absorption heat transformer. The intended application is to identify environmental improvements opportunities in the process involved.

The scope: The product system is an absorption heat transformer which recovers heat waste from an external source in the evaporator and generator.

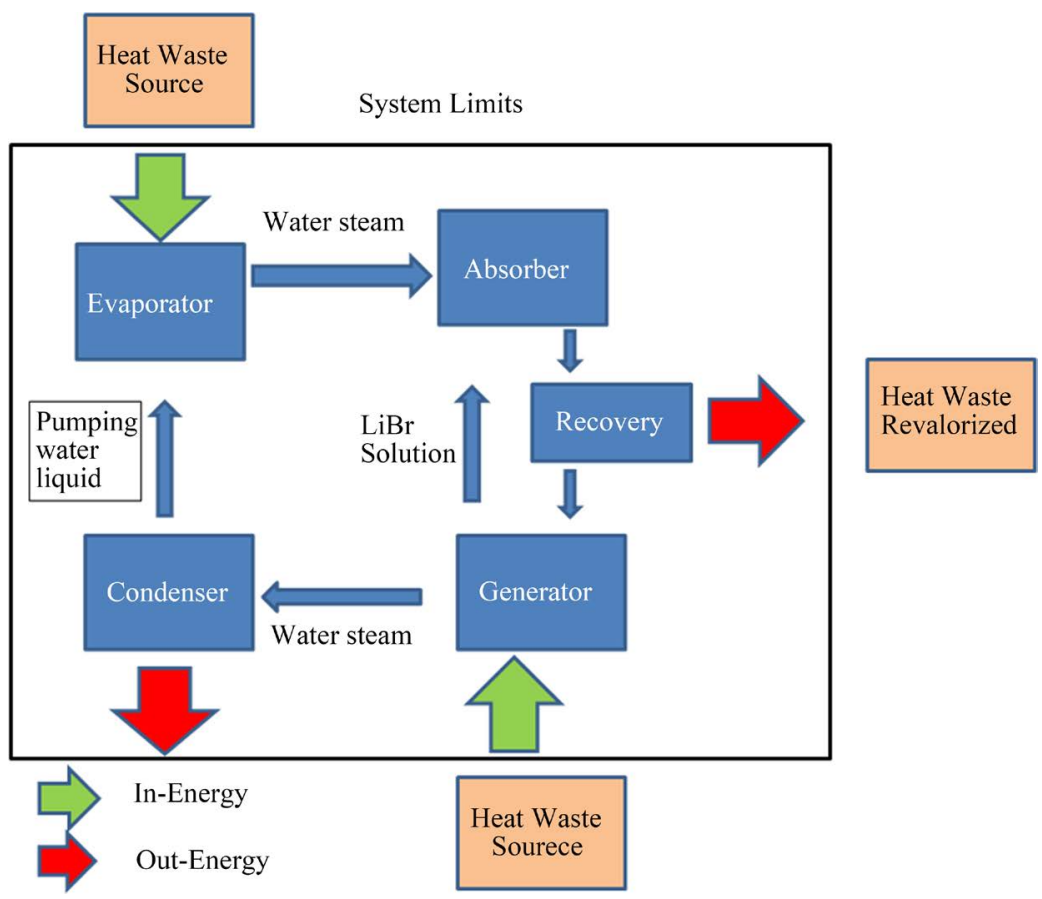

Figure 1. Absorption Heat Transformer system limits, schematic diagram.

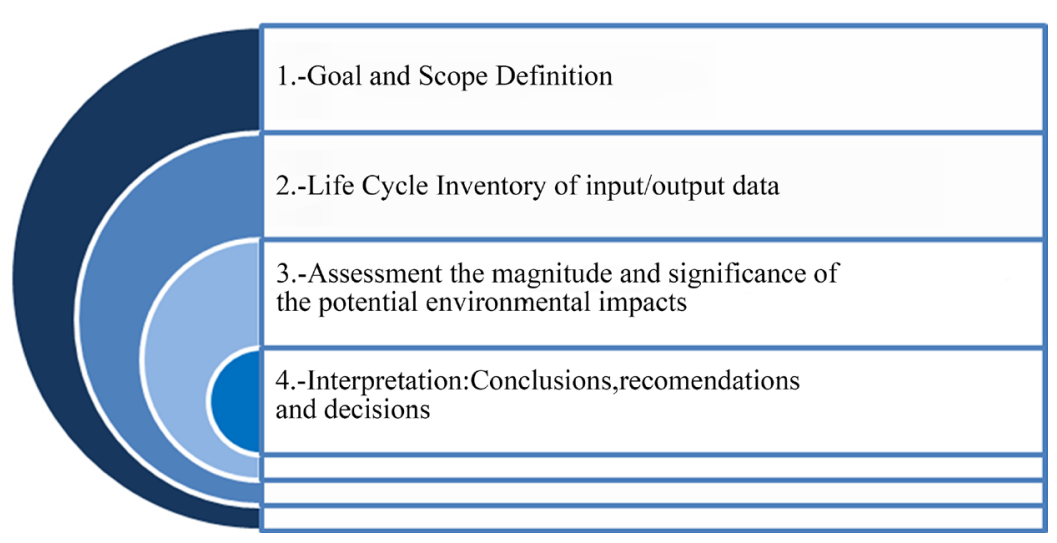

Figure 2. LCA of an AHT schematic diagram. 
The system boundary: Four processes are considered in this study (assembly, recovery, pumping and LiBr (Lithium Bromide) solution) and shown in Figure 1. The generator, condenser, evaporator and absorber process works in a cycle where the incoming Energy is the same than the salient Energy.

Allocation: there is not process shared with other products.

Functional Unit: The functional unit is $1 \mathrm{kWh}$ recovered for the system.

Data quality requirements: the data for assembly process were taken directly from the equipment and the data for all the other process were obtained from SimaPro software [13].

Assumptions:

- No energy loss in the system.

- The recovered energy is considered as electrical energy avoided.

- Assembly, lifetime: 40,000 hours.

- LiBr Solution, lifetime: 1000 hours.

\subsection{The Life Cycle Inventory Analysis Phase}

The Heat Transformer processes are: assembly, recovery, pumping and $\mathrm{LiBr}$ (Lithium Bromide) solution.

Tables 1-4 show the material list and input/output energy for each process.

Table 1. Material list of heat transformer assembly.

\begin{tabular}{ccc}
\hline Material & Quantity & Unit \\
\hline Steel, low-alloyed & 90.538 & $\mathrm{~kg}$ \\
Steel, chromium steel18/8 & 11.343 & $\mathrm{~kg}$ \\
Elastomere (Tube insulation) & 0.260 & $\mathrm{~kg}$ \\
Tetrafluoroethylene & 0.402 & $\mathrm{~kg}$ \\
Vinyl fluoride & 0.402 & $\mathrm{~kg}$ \\
Nylon 6-6 & 0.038 & $\mathrm{~kg}$ \\
Cable & 0.070 & $\mathrm{~kg}$ \\
Copper & 0.200 & $\mathrm{~kg}$ \\
\hline
\end{tabular}

Table 2. Material list of LiBr solution reaction.

\begin{tabular}{ccc}
\hline Material & Quantity & Unit \\
\hline Ethylene glycol & 0.3324 & $\mathrm{~kg}$ \\
Lithium hydroxide & 0.4125 & $\mathrm{~kg}$ \\
Bromine & 1.3935 & $\mathrm{~kg}$ \\
Tap water & 1.2187 & $\mathrm{~kg}$ \\
\hline
\end{tabular}

Table 3. Input/output of energy in the recovery process.

\begin{tabular}{ccc}
\hline Process & Quantity & Unit \\
\hline Generator & -1 & $\mathrm{kWh}$ \\
Condenser & +1 & $\mathrm{kWh}$ \\
Evaporator & -1 & $\mathrm{kWh}$ \\
Recovery & -1 & $\mathrm{kWh}$ \\
\hline
\end{tabular}

Note: The net contribution of energy of the system is in the Recovery Process. The negative value means that electrical energy $(\mathrm{kWh})$ is avoided.

Table 4. Input/output of energy in the pumping process (direct measurement in the system).

\begin{tabular}{ccc}
\hline Process & Quantity & Unit \\
\hline Pumping 1 & 0.030 & $\mathrm{kWh}$ \\
Pumping 2 & 0.030 & $\mathrm{kWh}$ \\
\hline
\end{tabular}




\subsection{Life Cycle Impact Assessment Phase}

Life cycle impact assessment phase (LCIA), aimed at understanding and evaluating the magnitude and significance of the potential environmental impacts for a product system throughout the life cycle of the product [7]. The impact potential assessment (IPA) is calculated with (1).

$$
I P A=\sum_{i=1}^{n} \text { Substance } i^{*} C F i \text {. }
$$

The Substances $i$ for climate change category are shown in Table 5. In Table 6, it shows the characterization factors (CFi) for climate change impact category. Equation (1) calculated the IPA is shown in Table 7.

In this phase the environmental effects of each process (assembly, recovery, pumping and LiBr solution reaction) are quantified and evaluated for the impact category Climate Change considered in this study, the impact is expressed in a common unit ( $\mathrm{kg} \mathrm{CO}_{2}$ equivalents)/(kg of Substance). The SIMAPRO software [13] was used to evaluate the impact potential assessment.

The negative values means the quantity avoided; as an example, in the heat transformer, the substance carbon dioxide from fossil fuel (-621.8310824 g) means than this quantity is avoided. In the assembly process the substance carbon dioxide from fossil fuel (5.596467 g) means than this quantity is emitted to environment.

\subsection{Life Cycle Interpretation}

The AHT system net contribution is an emission avoided of $0.665 \mathrm{~kg} \mathrm{CO}_{2}$ eq (see Figure 3).

Table 5. Inventory of substances of AHT [13].

\begin{tabular}{ccccccc}
\hline Substance & Unit & Heat Transformer & Assembly & Pumping & Solution LiBr & Recovery \\
\hline Methane, chlorodifluoro-, HCFC-22 & $\mathrm{mg}$ & 0.9930 & 1.0007 & 0.00051 & 0.0002308 & -0.008433 \\
Methane, trifluoro-, HFC-23 & $\mu \mathrm{g}$ & 63.746 & 63.766 & 0.00140 & 0.0021461 & -0.023326 \\
Sulfur hexafluoride & $\mu \mathrm{g}$ & -144.638329 & 0.193051 & 9.27570 & 0.4879222 & -154.5950 \\
Methane, fossil & $\mathrm{mg}$ & -826.836511 & 17.58988 & 55.55473 & 25.9310568 & -925.9122 \\
Dinitrogen monoxide & $\mathrm{mg}$ & -75.2300337 & 0.150714 & 4.844296 & 0.51322689 & -80.73827 \\
Carbon dioxide, fossil & $\mathrm{g}$ & -621.830824 & 5.596467 & 40.65573 & 9.51253638 & -677.5956 \\
\hline
\end{tabular}

Table 6. Characterization factors [13].

\begin{tabular}{|c|c|c|c|}
\hline \# & Sustance & Factor & Unit \\
\hline 1 & Methane, chlorodifluoro-, HCFC-22 & 1810 & $\mathrm{~kg} \mathrm{CO} \mathrm{CO}_{2}$ eq $\mathrm{kg}$ \\
\hline 2 & Methane, trifluoro-, HFC-23 & 14800 & $\mathrm{~kg} \mathrm{CO} \mathrm{CO}_{2} \mathrm{eq} / \mathrm{kg}$ \\
\hline 3 & Sulfur hexafluoride & 22800 & $\mathrm{~kg} \mathrm{CO} \mathrm{CO}_{2} \mathrm{eq} / \mathrm{kg}$ \\
\hline 4 & Methane, fossil & 25 & $\mathrm{~kg} \mathrm{CO} \mathrm{CO}_{2} \mathrm{eq} / \mathrm{kg}$ \\
\hline 5 & Dinitrogen monoxide & 298 & $\mathrm{~kg} \mathrm{CO} \mathrm{CO}_{2} \mathrm{eq} / \mathrm{kg}$ \\
\hline 6 & Carbon dioxide, fossil & 1 & $\mathrm{~kg} \mathrm{CO} 2 \mathrm{eq} / \mathrm{kg}$ \\
\hline
\end{tabular}

Table 7. Impact potential assessment results of AHT.

\begin{tabular}{|c|c|c|c|c|c|c|}
\hline Substance & Unit & Heat Transformer & Assembly & Pumping & Solution LiBr & Recovery \\
\hline Total & $\mathrm{kg} \mathrm{CO} \mathrm{CO}_{2}$ eq & -0.6652 & 0.00929 & 0.043715 & 0.01035 & -0.72859 \\
\hline Other substances & $\mathrm{kg} \mathrm{CO} \mathrm{CO}_{2}$ eq & 0.00024 & 0.00045 & $1.47 \mathrm{E}-05$ & $2.04 \mathrm{E}-05$ & -0.00025 \\
\hline Methane, chlorodifluoro-, HCFC-22 & $\mathrm{kg} \mathrm{CO}_{2}$ eq & 0.00180 & 0.00181 & $9.2 \mathrm{E}-07$ & $4.2 \mathrm{E}-07$ & $-1.53 \mathrm{E}-05$ \\
\hline Methane, trifluoro-, HFC-23 & $\mathrm{kg} \mathrm{CO}_{2}$ eq & 0.00094 & 0.00094 & $2.07 \mathrm{E}-08$ & $3.12 \mathrm{E}-08$ & $-3.45 \mathrm{E}-07$ \\
\hline Sulfur hexafluoride & $\mathrm{kg} \mathrm{CO} \mathrm{CO}_{2} \mathrm{eq}$ & -0.0033 & $4.40 \mathrm{E}-06$ & 0.000211 & $1.11 \mathrm{E}-05$ & -0.00352 \\
\hline Methane, fossil & $\mathrm{kg} \mathrm{CO} \mathrm{CO}_{2}$ eq & -0.0207 & 0.00044 & 0.001389 & 0.000648 & -0.02315 \\
\hline Dinitrogen monoxide & $\mathrm{kg} \mathrm{CO}_{2}$ eq & -0.0224 & $4.49 \mathrm{E}-05$ & 0.00144 & 0.00015 & -0.02406 \\
\hline
\end{tabular}




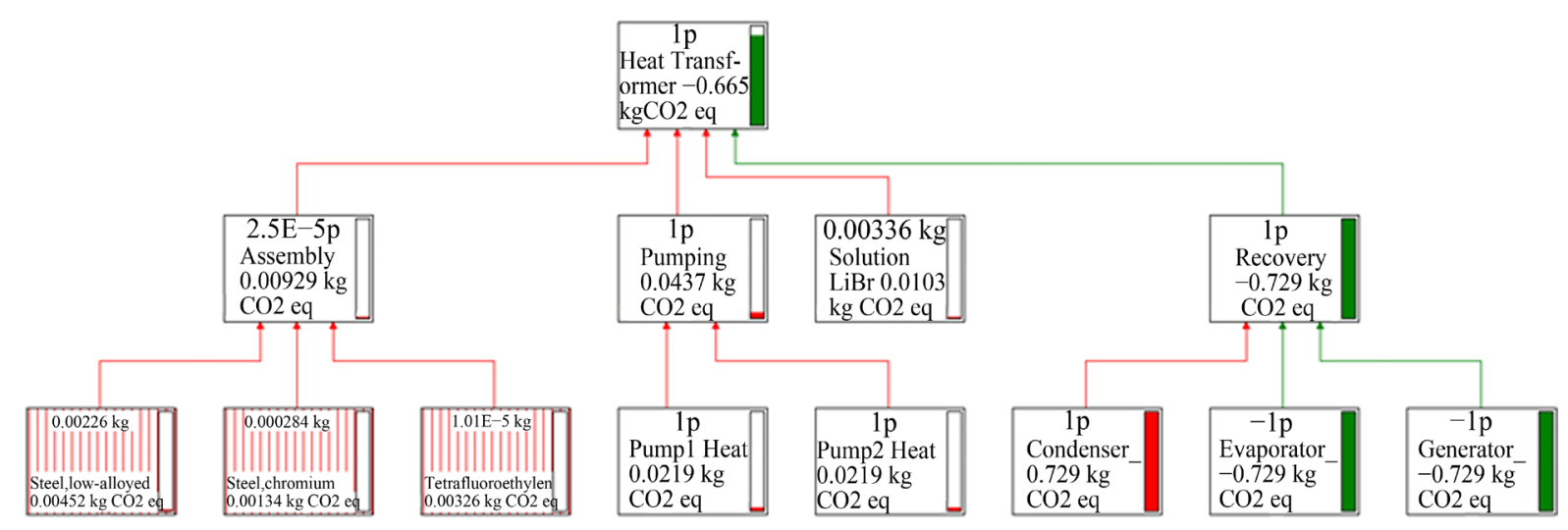

Figure 3. Results (kg of $\mathrm{CO}_{2}$ equivalents) of the environmental impact of the heat transformer system.

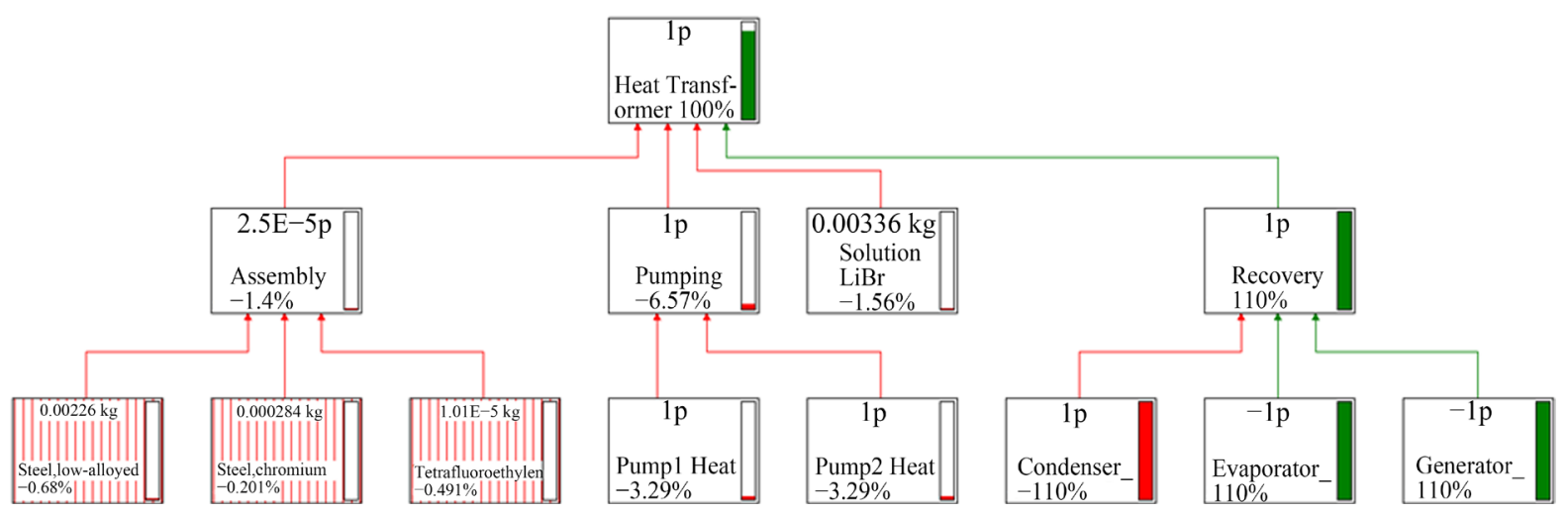

Figure 4. Results (\%) of the environmental impact of the heat transformer system.

The pumping process is the highest contributor to the environmental load (see Figure 3) with 0.0437 which correspond to $6.57 \%$ of the net contribution (see Figure 4). This process uses a source of electrical energy in the case of use another cleaner energy we can diminish the total impacts.

\section{Conclusions}

The efficient use of energy and minimum environmental impact of chemical processes are an important task today. By means of energy recovery systems, it is possible to improve the energy efficiency and the life cycle assessment is possible to evaluate the environmental impact of chemical processes. In the present work, the life cycle assessment of an absorption heat transformer which is designed to recover $1 \mathrm{kWh}$ of heat in 1 hour from each $2 \mathrm{kWh}$ of waste heat supplies in the generator and evaporator equipment was performed.

The life cycle assessment of the Absorption Heat Transformer shows that the substance with major emission is from carbon dioxide fossil to air. The net contribution of heat transformer is an emission avoided of $665 \mathrm{~g}$ $\mathrm{CO}_{2}$ eq. and the recovery process avoids $728.6 \mathrm{~g} \mathrm{CO}_{2}$ eq. and the major contribution to the environment impacts is the pumping process $43.7 \mathrm{~g} \mathrm{CO}_{2}$ eq. The pumping process is the main contribute to the environment impact emitted. This process uses a source of electrical energy that can be replaced with solar energy.

The environmental impact assessment of this Absorption Heat Transformer has shown that this technology can be a good option to recover waste energy in a sustainable way.

\section{Acknowledgements}

Authors thank to CB-167434 CONACYT project.

\section{References}

[1] International Energy Agency (IEA) (2015). Key World Energy Statistics. 
[2] Parham, K., Khamooshi, M., Tematio, D.B.K., Yari, M. and Atikol, U. (2014) Absorption Heat Transformers-A Comprehensive Review. Renewable and Sustainable Energy Reviews, 34, 430-452. http://dx.doi.org/10.1016/j.rser.2014.03.036

[3] Hdz-Jasso, A.M., Contreras-Valenzuela, M.R., Rodríguez-Martínez, A., Romero, R.J. and Venegas, M. (2015) Experimental Heat Transformer Monitoring Based on Linear Modelling and Statistical Control Process. Applied Thermal Engineering, 75, 1271-1286. http://dx.doi.org/10.1016/j.applthermaleng.2014.09.013

[4] Yin, J., Shi, L., Zhu, M.-S. and Han, L.-Z. (2000) Performance Analysis of an Absorption Heat Transformer with Different Working Fluid Combinations. Applied Energy, 67, 281-292. http://dx.doi.org/10.1016/S0306-2619(00)00024-6

[5] Ibarra-Bahena, J., Romero, R.J., Velazquez-Avelar, L., Valdez-Morales, C.V. and Galindo-Luna, Y.R. (2013) Evaluation of the Thermodynamic Effectiveness of a Plate Heat Exchanger Integrated into an Experimental Single Stage Heat Transformer Operating with Water/Carrol Mixture. Experimental Thermal and Fluid Science, 51, 257-263. http://dx.doi.org/10.1016/j.expthermflusci.2013.08.006

[6] Mimoso, A.F., Carvalho, A., Mendes, A.N. and Matos, H.A. (2015) Roadmap for Environmental Impact Retrofit in Chemical Processes through the Application of Life Cycle Assessment Methods. Journal of Cleaner Production, 90, 128-141. http://dx.doi.org/10.1016/j.jclepro.2014.11.057

[7] ISO 14040:2006. Environmental Management-Life Cycle Assessment-Principles and Framework.

[8] ISO 14044:2006. Environmental Management-Life Cycle Assessment-Requirements and Guidelines.

[9] European Commission-Joint Research Centre-Institute for Environment and Sustainability: International Reference Life Cycle Data System (ILCD) Handbook-General Guide for Life Cycle Assessment-Detailed Guidance. First edition March 2010, EUR 24708 EN. Publications Office of the European Union, Luxembourg.

[10] Donnellan, P., Cronin, K. and Byrne, E. (2015) Recycling Waste Heat Energy Using Vapour Absorption Heat Transformers: A Review. Renewable and Sustainable Energy Reviews, 42, 1290-1304. http://dx.doi.org/10.1016/j.rser.2014.11.002

[11] Rivera, W., Best, R., Cardoso, M.J. and Romero, R.J. (2015) A Review of Absorption Heat Transformers. Applied Thermal Engineering, 91, 654-670. http://dx.doi.org/10.1016/j.applthermaleng.2015.08.021

[12] (2013) SimaPro Database Manual Methods library.

[13] SimaPro Software, Versión 8.

\section{Submit or recommend next manuscript to SCIRP and we will provide best service for you:}

Accepting pre-submission inquiries through Email, Facebook, LinkedIn, Twitter, etc.

A wide selection of journals (inclusive of 9 subjects, more than 200 journals)

Providing 24-hour high-quality service

User-friendly online submission system

Fair and swift peer-review system

Efficient typesetting and proofreading procedure

Display of the result of downloads and visits, as well as the number of cited articles

Maximum dissemination of your research work

Submit your manuscript at: http://papersubmission.scirp.org/ 